\title{
The liver, the heart, and the brain
}

\author{
Francesco Scannelli and the body of painting
}

LORENZO PERICOLO

In the introduction to Leviathan (1651), Thomas Hobbes notes that man succeeds so well in imitating nature that, unknowingly, he is able to "make an artificial animal." "Why may we not say," he wonders, "that all automata (engines that move themselves by springs and wheels as doth a watch) have an artificial life?" Indeed, man's heart is "but a spring," the nerves "so many strings," and the joints "so many wheels giving motion to the whole body." The body politic, Hobbes insists, is also a human creation, a creature: "an artificial man." In keeping with this set of similes, Hobbes defines sovereignty as an "artificial soul ... giving life and motion to the whole body" and the members of the executive order as "artificial joints" linked to "reward and punishment" as if to "nerves." ${ }^{11}$ As construed by Hobbes, the body politic is not immune to pathological dysfunction; in the commonwealth, concord is health, sedition is sickness, and civil war is death. The physician and art theorist Francesco Scannelli (1616-63) is unlikely to have been acquainted with Hobbes's work.

1. T. Hobbes, Leviathan, or The Matter, Forme and Power of a Commonwealth, Ecclesiasticall and Civil, ed. M. Oakeshott (Oxford, 1946), 5. See also H. Bredekamp, Thomas Hobbes Visuelle Strategien: Der Leviathan, Urbild des modernen Staates (Berlin, 1999), esp. 61-65.

2. The critical literature on Francesco Scannelli is scant, and there is no study of his Microcosmo della pittura in light of its medical and philosophical underpinnings; I refer here only to very few studies in the field. All the translations are mine with the exceptions of those of ancient Greek texts (which I have slightly modified on a very few occasions). For a biography of Scannelli and his role in the purchase of paintings for the dukes of Modena, see R. Lepore in F. Scannelli, Il microcosmo della pittura (Forlì, 1989), 2:7-29. See also E. Cropper, "Ancients and Moderns: Alessandro Tassoni, Francesco Scannelli, and the Experience of Modern Art," Annali di Critica d'Arte 5 (2009): 81-101; J. L. Hutson, "Un modo più chiaro: Francesco Scannelli and the Physiology of Style," Storia dell'Arte 32 (2012): 95-124; Raffaello, Correggio, Caravaggio, un'esperienza tattile: Sulle orme di Scannelli, ed. C. Occhipinti (Rome, 2016); E. Cropper, "Theory and Practice Revisited: Francesco Scannelli between Giovan Battista Agucchi and Carlo Cesare Malvasia," in Arte dal naturale, ed. S. Ebert-Schifferer et al. (Rome, 2018), 129-50; and L. Pericolo, "Beyond Perfection: Guido Reni and the Fourth Age of Painting," in Malvasia's Felsina pittrice: Lives of the Bolognese Painters. Volume Nine: Life of Guido Reni, ed. E. Cropper and L. Pericolo (London and Turnhout, 2019), 2:1-132, esp. 31-50.
By endowing painting with a metaphorical body in his Microcosmo della pittura (1657), he was certainly not inspired by the cogent analogy at the core of Leviathan. However, Scannelli was assuredly fascinated with the notion of the body as a portentous machine, a fascination he shared with innumerable contemporaneous physicians and natural philosophers across Europe, among them René Descartes. In his treatises on man and the human body (which were unknown to Scannelli), Descartes goes so far as to interpret the entire operation of the human body as a nearly artificial mechanism, its organs operating similarly to "the motions of a watch, or some other automaton" triggered by "springs and wheels." 3 To be sure, Scannelli would never have espoused such an extreme conception of man's microcosm, that is, of the human body. The mechanics of Scannelli's body machine, in fact, still rely upon spiritual faculties pulling all the basic strings of man's physiologic activity. ${ }^{4}$ By the standards of his own time, Scannelli's ideas about the human body can hardly be considered cutting edge. Although he endorses the role of experience in medical theory by stressing the substantial importance of anatomic dissections and their findings, he chiefly refers to the works of earlier physicians and anatomists, showing no apparent interest in contemporary debates about medicine or, more broadly, the experimental sciences. Neither a pioneer nor an innovator, Scannelli does not belong in the league of Hobbes and Descartes. And yet, his redefinition of painting as an organic body is unprecedented and not entirely devoid of original insights. The primary hurdle to comprehending the essence of Scannelli's enterprise, and in probing its consistency, is the long-winded, at times unfocused, overly abstract, and oddly structured nature of his argumentations, which generate confusion and even disorientation. Additionally problematic are the

3. R. Descartes, L'Homme et la formation du foetus (Paris, 1664), 107. See also A. Vizier, "Descartes et les automates," MLN 111 (1996): $688-708$.

4. On the meaning and role of the faculties in ancient, medieval, and early modern natural philosophy, see The Faculties: A History, ed. D. Perler (Oxford, 2015). 
typographical errors scattered throughout the 1657 edition of the Microcosmo. In spite of these obstacles, however, it can be argued that Scannelli's physiological views on painting obey a relatively coherent design. The intention of this essay is to navigate Scannelli's text along a subtextual itinerary, following the leads offered by his marginal notes and reassembling the armature of his thought process in a different, more self-explanatory sequence.

In addressing the reader at the beginning of his Microcosmo, Scannelli claims to fear the prejudice of an audience that, "before reading, smells not only the title, but also the book's author as if it were a meal.". The reason for these scruples originates in Scannelli's profession; he is not a painter, but "a physician and surgeon who has taken to writing about painting. ${ }^{\prime \prime}$ In reality, Scannelli must have prided himself on the new methodology he was adopting both in defining painting and in reconstructing its "biological" configuration and evolution. As a physician, Scannelli had resolved from the outset to venture into art theory only by beating a very conventional path. In his opinion, what painting is and where its perfection resides are a matter of common sense or, more specifically, self-evidence. Yet, "in discussing and revealing the effects of noble painting ... the opinions are so numerous and varied that one finds the truth to be faked and reality counterfeited and adulterated." For the physician, the hermeneutic obscurity in which painting had become entangled makes little sense. First and foremost, painting is "the delightful and appropriate object of the worthiest sense of sight, which ... among the senses, is considered to be the least susceptible to deceit." Moreover, "painting is more perspicuous and manifest than any other object more opaque to sight and cognition." vision," painting reenacts seeing and aims to be seen. Because it is the product of sight, acts like sight, and is processed through sight, painting should entail immediate knowledge and produce instantaneous evidence. To underscore the point, Scannelli grounds his conviction in Aristotle's authority. At the beginning of book 2 of On the Soul, Aristotle likens the coordination of body and soul to the functioning of sight: "If the eye were a living creature, its soul would be its vision, for

5. F. Scannelli, /l microcosmo della pittura (Cesena, 1657), n.p.

6. For the interest in painting and art theory of a more prominent seventeenth-century physician in Rome, see F. Gage, Painting as Medicine in Early Modern Rome: Giulio Mancini and the Efficacy of Art (University Park, PA, 2016).

7. Scannelli, Microcosmo, 5. this is the substance (in the sense of the rationale) of the eye; but the eye is the matter of vision, and if vision fails, there is no eye ... the body is that which exists potentially, but just as the pupil and the faculty of seeing make an eye, so in the other case the soul and body make a living creature. ${ }^{\prime \prime}$ By referencing this passage, Scannelli intimates that sight is the basic function of the soul, and that no soul can effectively perform its tasks if deprived of vision. Of course, this was not exactly the gist of Aristotle's brief simile, but it is relevant that for the physician Scannelli, the soul both physiologically and metaphorically acts through and analogously to the seeing eye. It should be noted that Scannelli does not content himself with the widespread topos of sight as the noblest sense in creating and supporting knowledge. Scannelli in fact construes seeing as a spiritual faculty, much in keeping with his notion of painting as a perfected vision of natural beauty. I shall return to this point later.

If painting is by definition self-evident (as Scannelli declares), then it remained to explain why no unanimity had been reached about its nature, and to uncover the reasons for persistent misinterpretation and misjudgment. As for many other art writers of the period, for Scannelli the primary source of trouble was Giorgio Vasari. Without naming him outright, Scannelli blames the imperfect knowledge and defective sight of those who, driven by excessive passion, had confused the minds of future generations by celebrating "their own homelands and nations" or by being unable to recognize "the work of true masters." ${ }^{\prime \prime}$ In other words, misunderstanding results from the absence of a moderate and moderating reason. Scannelli expresses this principle more plainly when he points out that adequate knowledge is achieved when the beholder studies the object at the right distance (again, an epistemological procedure likened to seeing). In this respect, Scannelli remarks that he found himself "at the due distance in regard to the works and homelands of the worthiest artists," and therefore his conclusions, bereft of "affected partiality," ought to be marked by selflessness and objectivity. With impartiality, then, he endeavored to unveil "the pure and coveted truth" only insofar as his views could be corroborated "in the eyes of authority and of the reasonable." ${ }^{10}$ By authority, Scannelli means both the authors of canonical art treatises and the foundational

8. Aristotle, On the Soul, Parva Naturalia, On Breath, ed. and trans. W. S. Hett (Cambridge, MA, 1958), 71-73.

9. Scannelli, Microcosmo, 6.

10. Scannelli, Microcosmo, n.p. 
writings of the Aristotelian and Galenic medical tradition. In Scannelli's opinion, truth cannot affirm itself without an intense dialogue with "authority." While he often disagrees with past art writers, however, Scannelli rarely takes issue with the venerable authors of ancient medicine and natural philosophy. In a sense, he turns the authoritative principles of his own profession into the indisputable premises of a new hermeneutics, one thoroughly committed to a global understanding of painting in conformity with a network of analogical correspondences. Aware of the pitfalls involved in the procedure of fashioning an interpretation of painting on a physiological model, Scannelli admits that parallels can fall short if one expects to find a one-to-one equivalence between the functions and organs of the human body and those of painting. Nevertheless, scholars "will most clearly recognize in the microcosm of painting the main and noblest parts [of the human body] that impart [it] its form, as well as nourishment, life, and intelligence, along with feeling, motion, and preservation."11

As a natural "composite," the human body owes its functioning to a harmonious interaction of organs. "Natural philosophers," Scannelli argues, "have unanimously demonstrated that the liver, together with the heart and brain, are granted primacy over man's microcosm, because the virtue of nourishment, heat, and intelligence derives from these principles as from its true source."12 In Scannelli's words, the liver, heart, and brain are not only the principal organs, but they also stand for the logical principles (principi) of man's basic physiological operations. Just like its human counterpart, the body of painting must be considered a theoretical construct. In fact, Scannelli focuses not on an individual body, with its accidents and imperfections, but on the perfected body of painting, which perfectly mirrors the medical body of health. In this regard, Scannelli upholds the opinion of Galen, who remarks that "whoever wishes to know a defective figure, must first understand it in its most perfect state of health."13 This is the core of the first paragraph of Galen's Elementary Course on Bones. ${ }^{14}$ In Galen's observation, nature is given a normative task, such that physicians cure anomalies and

11. Scannelli, Microcosmo, 11.

12. Scannelli, Microcosmo, 11.

13. Scannelli, Microcosmo, 130.

14. A translation of Galen's De ossibus ad tirones is provided in C. Singer, "Galen's Elementary Course on Bones," Proceedings of the Royal Society of Medicine 45 (1952): 767-76 (see esp. 768). distortions by restoring the body to its normative state. By the same token, Scannelli argues for the necessity of a normative rule as the prerequisite of knowledge, thus grounding his definition of painting in an aesthetic paradigm centered upon the notion of perfect nature. Like Vasari, but with greater dogmatism, Scannelli subsumes the historical development of painting under an atemporal notion of perfection. In fact, Scannelli's perspective on painting pivots around a canonical past. Art soars to its apogee through the work of masters who, at a certain point in time, coexist: Raphael, Titian, and Correggio. In opposition to Vasari, Scannelli dethrones Michelangelo as the embodiment of artistic perfection, replacing him with Correggio, who becomes Michelangelo's perfected alter ego. After Correggio, if art does not quite cease to exist, it nevertheless surrenders most of its capacity for innovation. As a consequence, history plays a minor, yet complementary, role in Scannelli's interpretation of painting. In the Microcosmo, any notion of development is strictly "physiological": it designates the steps through which painting fulfills its natural process of growth toward its predetermined perfection.

The interconnection between the human microcosm (the body) and the macrocosm (the universe as formed through divine providence) had been a cornerstone of the natural sciences since antiquity. In his Historia anatomica (first published in 1600), the French physician André du Laurens exhumes and revamps this wellestablished homology between the human and the natural cosmos: ${ }^{15}$ "Just as the soul is the noblest of the forms under the disk of the moon, so too does the human body, which hosts the soul, excel so greatly above all others that it can be called the measure ( $\mu \varepsilon \varepsilon^{\prime} \rho v_{\text {) }}$ and rule of all the bodily things. ... It admirably encompasses and contains in itself all the things comprised under nature's law and dominion. Indeed, we can find in it the lively image of that entirety we see before our eyes as if it were represented in a mirror or in a small painting."16 In making the human body the "measure and rule" of painting, Scannelli, who explicitly refers in his Microcosmo to the Historia anatomica, was persuaded that he was applying to the artistic field the most compelling and unimpeachable

15. For a survey of the life and career of André du Laurens, see the introduction by R. Suciu to A. du Laurens, Discours des maladies mélancoliques (1594) (Geneva, 2012).

16. André du Laurens, Historia anatomica humani corporis partes singulas uberrime enodans novisque controversiis et observationibus illustrata (Lyons, 1605), 4-5. 
hermeneutical system at his disposal. By demonstrating that painting should be analyzed and dissected on par with the human microcosm, Scannelli was accomplishing his most considerable feat. In his eyes, only the recourse to the principles of natural philosophy and medicine could ensure the infallibility of his demonstration. In praising the human body, du Laurens

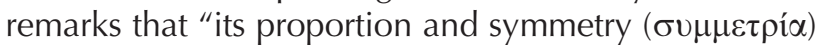
are so astounding" that "artists take it as an example, architects refer everything to it just as to the rule of Polycleitos; on its model they build their temples, houses, machines, and ships; and it is even believed that Noah's ark was made in conformity with the measurements of the human body."17 On these grounds, it was easy for Scannelli to shift from a physiological to an aesthetic mode of interpretation, all the more so because the human body had inspired the practices of sculpture and architecture since ancient Greece. In his Historia anatomica, du Laurens goes farther: "The ancient magi and the Egyptian priests considered the universe to be made of three parts: the loftiest one, which they term intellective and angelic, is the seat of the intelligences through which all the inferior things are governed and moderated; the middle one, called celestial, is presided over at its center by the sun, which (as it were) is the leader and moderator of all the stars; the third one, sublunary or elementary, is admirably fertile in producing, growing, and nourishing both animals and plants." ${ }^{\prime 18}$ Convinced of the validity of this tripartite cosmology, du Laurens contends that, in the case of the human body, the head is "the fortress of human understanding, the seat of reason, the abode of wisdom, memory, judgment, the arsenal of thoughts." 19 Following this analogy, the head logically corresponds to "the superior and angelic part of the world."20 Consequently, the middle part of the cosmos is to be equated with "the chest and the mid-section of the stomach." ${ }^{21}$ In du Laurens's view, "some of the ancients did not hesitate to call the sun the heart of the world, and the heart the sun of man." 22 Just as the sun through its radiant heat causes the world to procreate and thrive, so too "through the perpetual motion of the heart and its vital heat is this microcosm (parvus mundus) restored and preserved and perpetuated in its vigor. ${ }^{\prime 23} \mathrm{Du}$

17. Du Laurens, Historia anatomica, 5-6.

18. Du Laurens, Historia anatomica, 6.

19. Du Laurens, Historia anatomica, 6.

20. Du Laurens, Historia anatomica, 6.

21. Du Laurens, Historia anatomica, 6

22. Du Laurens, Historia anatomica, 6.

23. Du Laurens, Historia anatomica, 7
Laurens expands on the interrelationship between the head and the heart by describing the function of the former as analogous to that of the motor immobilis in Aristotle's Metaphysics. ${ }^{24}$ While the head (more specifically, the brain) animates the body with its spiritual faculties by transmitting to it the impulse to move, the heart keeps the body in motion by ensuring its growth and vigor. In du Laurens's physiology, the sublunary or elementary part of the body is associated with the organs of the lower abdomen, its operations primarily consisting of providing nourishment and securing procreation. More specifically, Du Laurens singles out the function of the genitalia, the liver, the bladder, and the spleen. Although he extols the liver as "a fountain and source of a graceful vapor," he does not rank it as the major organ of the sublunary body. ${ }^{25}$

To a great extent, Scannelli's adoption of a tripartite structure of the body as a model for painting is indebted to du Laurens's Historia anatomica. Even though the liver is not a primordial part of the human body in du Laurens's opinion, its preeminence was deeply entrenched in early modern medical theory. In discussing the interrelation between the liver, the heart, and the brain, Scannelli relies, for instance, on the Epistolae medicinales (first published in 1521) by the Ferrarese physician Giovanni Manardo (1462-1536). ${ }^{26}$ In epistle 4 of book 4, which Manardo had conceived of as a general definition of medicine as a science, he clearly states that the liver, the heart, and the brain are the three principal organs insofar as they are "necessary for the preservation of the individual." In the liver, heart, and brain, Manardo insists, reside the "principal faculties" (principes potestates) of the human body. ${ }^{27}$ Manardo's explication is both succinct and lucid: "The brain is the seat of the faculty of the soul, which is twofold, namely, motory and cognitive, extending throughout the entire body through the nerves disseminated in it. Through the natural faculty dwelling in it, the liver generates the blood and the other humors, which it distributes to the entire body through the veins

24. Du Laurens, Historia anatomica, 7

25. Du Laurens, Historia anatomica, 7.

26. On Manardo, see the essays in Atti del Convegno Internazionale per la celebrazione del $V$ centenario della nascita di Giovanni Manardo, 1462-1536, ed. K. Arady (Ferrara, 1963). On medicine in Ferrara in the age of humanism, see V. Nutton, "The Rise of Medical Humanism: Ferrara, 1464-1555," Renaissance Studies 11 (1997): 2-19. On the genre and function of medical epistles, see

N. G. Siraisi, Communities of Learned Experience: Epistolary Medicine in the Renaissance (Baltimore, 2013).

27. G. Manardo, Epistolarum medicinalium libri duodeviginti (Basel, 1535), 46. 
in order to provide nourishment. The heart is the source of life due to the vital spirit it generates, which, conveyed through the arteries, supplies life to all the most minute parts [of the body]." ${ }^{28}$ Manardo here develops ideas that had already been formulated by Galen. For example, in On the Usefulness of the Parts of the Body, Galen writes: "Nature had three principal aims in constructing the parts of the animal; for she made them either for the sake of life (the brain, heart, and liver), or for a better life (the eyes, ears, and nostrils), or for the continuance of the race (the pudenda, testes, and uteri)." ${ }^{29}$ Once Scannelli realized that the mechanics of the human machine could be used to irrefutably and transparently explain the functioning of painting, he must have faced the problem of figuring out how the principal tasks of cognition, vitality, and nourishment might be articulated in artistic terms. Of course, it is impossible to establish how Scannelli ultimately arrived at a notion of painting as a half-natural, half-artificial body marked not only by physiological functions, but composed of the symbolic bodies of all artists. As a metaphorical entity, Scannelli's "Painting" (a prosopopeia) in fact amalgamates Raphael and Titian, Michelangelo and Correggio, and many other artists, their number potentially infinite. From the very beginning, Scannelli must have decided that Correggio should be given primacy by making him accomplish the functions of the brain, thereby downgrading Michelangelo, who might have been arguably deemed Vasari's "brain." The question of which organ Michelangelo should then embody must have preoccupied Scannelli. In his opinion, Michelangelo could and should not be defined as a principal organ of painting: he neither fed nor animated painting and therefore could not be compared with Raphael (the liver) and Titian (the heart). While it is true that few in Scannelli's time would have sponsored Michelangelo's supremacy, it was always risky to dismiss altogether Vasari's taxonomy as simply ungrounded. Scannelli's solution was to turn Michelangelo into a counterpart of the spinal cord. This solution enabled Scannelli to cast Michelangelo in positive terms as the armature of painting:

It is with every reason that we can indeed compare Michelangelo with the spinal cord of the microcosm of painting, which philosophers and good anatomists

28. Manardo, Epistolarum, 46.

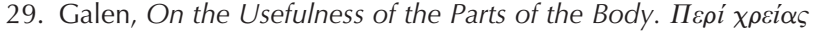
$\mu o \rho i \omega \nu$. De usu partium, ed. and trans. M. T. May (Ithaca, NY, 1968), 2:620. commonly consider to be the base and true principle of the skeleton, as the keel is the foundation and base of the ship, and which consequently is the real framework of man's stupendous conformation. In the same way, the most knowledgeable Buonarroti was the first to contribute to the architecture of such a great machine, and laid solid foundations ... so that others after him with more qualified prerogatives easily managed to add [to these foundations] the achievement of fitting proportions. ${ }^{30}$

This is one of the rare passages in the Microcosmo in which Scannelli suggests not only a structural but also a historical approach to painting. As the harbinger of the "first school" of painting, Michelangelo had paved the way to Raphael, who, in Scannelli's estimation, "among all others has brought to the modern age the true state of a most flourishing and perfect youth." ${ }^{31}$ Implicit in Scannelli's statement is the idea that Michelangelo represents the infancy of painting, preceding in due course Raphael, who incarnates the vigor of a youthful organism. To better understand Scannelli's point of view, it is imperative to browse through his philosophical and medical sources. Aristotle, in his History of Animals, for example, remarks that "the bones in the animal are all connected with one single bone, and are a continuous system." ${ }^{\prime 32}$ A single and potentially pliable structure, the skeleton allows for stability and motion. Galen, in book 3 of On the Usefulness of the Parts of the Body, stresses the resemblance of the spine to a keel. ${ }^{33}$ In a crucial observation referenced directly by Scannelli, Galen illustrates the vital importance of the spinal medulla: "Since the spinal medulla was formed to be like a second brain for the parts below the head ... it had to be protected by a hard enclosure resistant to injury, and since this enclosure had to be made and put somewhere, was it not better to scoop out the keel, so to speak, which underlies the body of the animal as a foundation and is of course entirely bony, and to make its center hollow so as to form a pathway and at the same time a safeguard for the spinal medulla?" ${ }^{34}$ For Scannelli, Michelangelo's excellence was exemplary of Vasari's notion of disegno. With a bold critical independence, Scannelli radically modifies the definition of disegno, which remains foundational yet becomes subordinated to painting. In other words, the goal of disegno ceases to be disegno itself; the gamut of artistic

\footnotetext{
30. Scannelli, Microcosmo, 9.

31. Scannelli, Microcosmo, 11.

32. Aristotle, Historia animalium, ed. and trans. A. L. Peck (Cambridge, MA, 1965), 1:191.

33. Galen, On the Usefulness, 1:159.

34. Galen, On the Usefulness, 2:573.
} 
skills deemed specific to Michelangelo guarantees the stability and smooth functioning of the principal organs of painting, but in and of itself Michelangelo's "spinal cord" is mostly a "keel" or a "pathway" of the pictorial microcosm. Scannelli's new interpretation of Michelangelo's disegno, however, has its own theoretical complications. The intrinsic connection drawn between Michelangelo and Raphael in terms of a conceptual and historical affinity does not find its equivalent in the relationship between the spinal cord and the liver in the human body. Indeed, there is no ground for postulating a special link between these two organs. Whether or not Scannelli was aware of this significant logical (or analogical) discrepancy in his theory, it is undeniable that he perceived Raphael's activity as resulting directly from and improving upon Michelangelo's.

In Scannelli's eyes, Raphael's greatest merit resides in his selection "of the most perfect vestiges of antiquity" as objects of diligent study. But how does this link up with the task of the liver? Here is Scannelli's explication:

The liver, once it had obtained the form of its first lineaments, receives from the blood of the mother the achievement and perfection of its being. And Raphael extracts the substance of his knowledge from mother antiquity as if from veins destined for painting on account of their compatible humor. The liver absorbs the subtlest and most proportionate part from the aforementioned blood. In proportion to the hardness of the stones and bronzes of the statues Raphael draws out the subtleness and delicacy of artifice, transmuted into the delicacy of his own good painting. By forming and reforming itself, the liver then serves as the source conveying in turn the blood to all the other organs of the body, and along with it, the necessary spirits. With his extraordinary judgment and assiduous study, Raphael accomplishes in himself the true form of good painting and through his works, as its fountainhead or motherlode, he unceasingly passes down to the other painters the most suited substance and, annexed with it, the spirit of a perfect way of working. ${ }^{35}$

It is noteworthy that Scannelli concentrates not only on the role of the liver in providing blood and nutrition to the entire body, but also on its development and action at the embryonic stage and its strategic connection with the heart and brain. That these were not secondary questions for Scannelli is confirmed by his discussion of the differing opinions concerning the formation and preeminence of the liver:
Although the liver comes to be formed as if simultaneously with the other parts in conformity with the testimony of that ever great master who first studied the effects of the human nature [Hippocrates], afterward others more expert in the practice of anatomical research have demonstrated with reason and clear evidence that the liver, because it first receives the most immediate substance of the maternal viscera, is the first to be nourished, subsequently conveying [that substance] to the heart, and from the heart to the brain, and in this way it never stops supplying these two organs with nourishment, and, together with the other principal organs, the spirit and heat [necessary] for the new organism. ${ }^{36}$

In his De naturali parte medicinae (first published in 1542), the French physician Jean Fernel attacks Aristotle's conviction that the heart, because "it is the origin of both veins and arteries, and the principle of motion and the nutritional faculty," is the first organ to be formed in the fetus. ${ }^{37}$ Modern medicine, Fernel asserts, cannot approve of Aristotle's views. ${ }^{38}$ Fernel's reasoning takes its point of departure from a structural comparison between plants and animals:

The first kind of life that is called natural resides in man at a higher degree of perfection and more vigorously than in plants. The latter live, indeed, as much as they feed and grow, but not by dint of the heat and vital spirit that, in animals, comes from the heart, because plants do not have a heart or anything that analogically corresponds to it. Recently formed from the semen, the fetus is unlikely to contain within itself anything more effective than the plants, and indeed, insofar as the heart is not yet formed, it lives and feeds just like the plants. ${ }^{39}$

Although predicated upon an analogical discourse, Fernel's theory that the initial stage of life relied on the liver remained highly speculative. This might not have eluded Scannelli, who, after referring to Fernel in his Microcosmo, adds a reference to the Anatomicae praelectiones (first published in 1586) by the Ferrarese

36. Scannelli, Microcosmo, 12-13.

37. J. Fernel, De naturali parte medicinae libri septem (Paris, 1542), 157.

38. On Fernel's ideas and influence in early modern medicine, see L. Figard, Un médecin philosophe au XVle siècle: Étude sur la psychologie de Jean Fernel (Paris, 1903); C. Sherrington, The Endeavour of Jean Fernel, with a List of the Editions of His Writings (Cambridge, 1946); and L. D. Richardson, Academic Theories of Generation in the Renaissance: The Contemporaries and Successors of Jean Fernel (1497-1558) (New York, 2018).

39. Fernel, De naturali, 158. 
physician Arcangelo Piccolomini (1525-86). ${ }^{40}$ In a chapter consecrated to the "excellence of the liver," Piccolomini reports the groundbreaking results of a vivisection he had performed on a pregnant dog:

Mark this: after dissecting and opening the uterus, there come into view (a portentous thing to see and relate!) three bubbles of some sort, like three pearls, of the size of a rather large pea, most white and bright, and enfolded within extremely fine and diaphanous, almost pellucid, membranes. And immediately I recognized the utter truth of what the most learned Fernel in his book on man's procreation had celebrated with his words in mentioning these three parts [the liver, the heart, and the brain] ... I began to admire and contemplate these bubbles and to touch them delicately with my hands. They were placed in such a way that one was on top, another in the middle, and the last one at the bottom, and the distance among them was smaller than an inch; at first glance, they appeared to be detached and without anything linking them together. However, when I grabbed them with my hands and observed them against a source of light, they appeared to be joined together through almost numberless filaments, most tenuous and white at the same time, stretching from the upper bubble to the middle one, and from this to the lower one, upward and downward and in any direction. Two droplets of blood were attached to the lower part of the bubble at the bottom; from there they were carried to the umbilical vein. These things aroused in me so much astonishment that I became ecstatic ( $\sigma \tau \tau \alpha \tau \iota \kappa o ́ \varsigma)$. Recovering my senses, I was filled with immeasurable pleasure because this very examination removed all the qualms I still harbored and I realized how little the reasonings and other frenzies of Aristotle and Galen mattered. From this observation and examination, thus, I recognized that these three bubbles were the first basic organs, the brain, the heart, and the liver, coexisting in the semen, in their pristine configuration and formed together at the same time. ${ }^{41}$

The anatomical experience recorded by Piccolomini was exceptionally valuable for Scannelli because it not only confirmed Fernel's theory but, more particularly, corroborated the prerogative of the liver in the evolution of the fetus. It may seem strange that an anatomical discovery regarding the development of the human fetus should play such a prominent role in the Microcosmo, even though its importance for Scannelli goes almost unnoticed, concealed as it is among his marginal notes.

40. On Piccolomini, see F. Pierro, Arcangelo Piccolomini ferrarese (1525-1586) e la sua importanza nell'anatomia postvesaliana (Ferrara, 1965).

41. Arcangelo Piccolomini, Anatomicae praelectiones (Rome, 1586), 123.
Through experimentation, Piccolomini had substantiated Fernel's intuition based on a logical and analogical assumption. Once authenticated, Fernel's conviction that the liver preceded the heart in man's embryonic growth could be turned by Scannelli into an epistemological principle and compellingly applied to any physiological discourse. That nutrition (the liver) is achieved prior to animated life (the heart) delineates a cause-and-effect mechanism that presupposes a logic of development in time and adumbrates a historical sequence when extended to the explanation of a physiological evolution of the arts. It is the "if $x$, then $y$ " of the organic equation that, when tested and validated through experience (anatomic dissection), mattered for Scannelli: in fact, it constituted a logical device capable of validating his explanation of painting's homologous physiology. Like Piccolomini, Scannelli believed that his physiological assumptions could be verified and corroborated through experience. For Scannelli, the effects of the artwork on the beholder indicate the extent to which the mechanism of painting is successful and whether it is adequately configured.

In this light, it is possible to discern the logic underpinning Scannelli's interpretation of the functions accomplished by Raphael-the-liver: the metabolization of the ancient canon into a distilled substance destined to support and enrich the craft and artistry of subsequent masters. It is worth noting that Scannelli's body of painting should not be identified with, although it is ancestrally related to, antiquity. Indeed, Scannelli dismisses ancient art as an unsurpassed paradigm of perfection. In his eyes, antiquity and Michelangelo retain the same defects: hardness. The bony substance of which Michelangelo's "spinal cord" is made could also be construed as the unmetabolized fossil of antiquity as embodied in ancient sculpture. Raphael alone had managed to alchemically distill delicacy from the hardness of stone: to transform antiquity and its elaboration by Michelangelo into matter for painting. ${ }^{42}$

Once again, the physiological analogy presents some hurdles since the task of transforming solid and hard food into blood is not exclusively fulfilled by the liver. In On the Usefulness of the Parts of the Body, Galen clarifies that the liver receives "the nutriment already prepared" by the stomach and the veins, which

42. Scannelli's criticism of the Tuscan-Roman artistic tradition on account of its dryness is part of the broader debate about the "statuino" (the characteristic hardness present in painted figures inspired by the example of ancient sculpture). See L. Pericolo, "Statuino: An Undercurrent of Anticlassicism in Italian Baroque Art Theory," Art History 38 (2015): 862-89. 
possesses "the crude outline, as it were, and indistinct semblance of blood," thereby giving rise to "the final elaboration itself so that the nutriment becomes actual blood." ${ }^{43}$ Galen poetically notes that "the humor prepared in the liver for the nourishment of the animal . . . after it has been completely concocted by the innate heat . . . becomes pure and red and rises to the convex portion of the liver, showing the color it has received from the cutting action of divine fire and the impression of that fire upon a moist substance." Scannelli seems to have had in mind this process of sublimation and rarefaction when he attributed it to the operations of Raphael-the-liver. It is hardly a coincidence that for Scannelli the "innate heat" necessary for the transformation of antiquity into pictorial delicacy is to be found in Raphael's diligence. At the beginning of his career, Raphael's "most delicate and excellent taste had chosen the perfection of antiquity as its most abundant and qualified nourishment." By making this choice, Raphael had "through the proportionate matter and the heat of studious labor ... extracted and formed the purest gold of finest painting." 44 For Scannelli, Raphael's sense of measure and moderation corresponds to the right amount of heat necessary for digestion and the transformation of food into blood. It is his moderate heat (or balanced diligence in studying antiquity) that determines the specific place of Raphael in the artistic canon. In the Microcosmo, Scannelli indeed blames the unpleasant dryness found in certain paintings as a consequence of an obstinate study of drawing and antiquity. He illustrates this phenomenon with the use of a digestive analogy: "Just as the heat, acting beyond measure upon the matter, tends to render charred what is raw, so too do painters through long and vicious diligence come easily to acquire an ensuing dryness in their works, which sometimes taps into the excesses of vice." 45 Like a well-tempered liver, Raphael refines antiquity without drying it up, contrary to Michelangelo, who is by definition as dry as a spinal cord.

As the liver of painting, however, Raphael does not rank as high as Titian (the heart) or Correggio (the brain). Scannelli's identification of Titian as the heart of painting is both less problematic and more generic than his characterization of Raphael: "Just as the heart, after receiving the humor from the liver, never ceases to perfect it and enrich it with the exceeding heat of the vital spirits, so too does the spirited Titian show himself

43. Galen, On the Usefulness, 1:205.

44. Scannelli, Microcosmo, 34.

45. Scannelli, Microcosmo, 305. congenial to an organ of such excellence." ${ }^{46}$ Resolving the analogy, Scannelli points out that "Titian causes the life of this art, which is grounded upon the most vigorous and true style, to spring forth." 47 While the analogical parallel between Raphael and the liver is predicated upon a complex variety of factors (Scannelli seems to have deliberated over this for some time), the relationship between Titian and the heart rests on more elusive grounds. In keeping with his medical authorities, Scannelli views the heart as synonymous with vitality and vigor. In assimilating Titian to the heart, Scannelli was no doubt thinking of the master's proverbial excellence in depicting the "vera carne," that is, "the life of flesh," and, on that score, he was aiming at contrasting Raphael's delicate draftsmanship with Titian's vigorous coloring. Nevertheless, in characterizing Titian's art, Scannelli equally bestows upon it some of the features that qualify Raphael's: "Endowed with a greater talent, our Titian, upon observing the worthiest truth disseminated by nature in the variety of its subjects, was able at once to most felicitously produce and muster a distillate of the most beautiful limbs (such as heads, hands and feet, arms and legs, thighs and torsos), which, marvelously interconnected with one another, together display an excellent [bodily] compound. This reveals a particular idea of rare beauty, because, as if formed of the truth, it shows the truest appearance of the living flesh [vera carne] with sweet softness and outstanding delicacy." 48 In a sense, for Scannelli, Titian is an improved and revised Raphael, with the significant addition of the "vera carne." Titian's delicacy, then, like Raphael's, is the product of distillation (in Titian's case from nature, and not from antiquity). The highest degree of life in Titian's painting logically derives from its greater proximity to nature. Raphael's naturalness is at a further remove from nature due to its indebtedness to the ancient canon, which is nothing but nature perceived through the filter of art, and therefore a surrogate. Scannelli in turn construes Correggio as an improved and revised Titian: a divinized Titian. Correggio's supremacy is Scannelli's most groundbreaking discovery as an art theorist and his true mark of novelty. While Scannelli presents Correggio's preeminence as selfevident, agreement on such a proposal was far from unanimous. Many previous commentators, Scannelli admits, balked at acknowledging the absolute

46. Scannelli, Microcosmo, 13.

47. Scannelli, Microcosmo, 13.

48. Scannelli, Microcosmo, 221. 
excellence of Correggio. "Although he was truly a bright sun of painting," Scannelli laments, "at his time people did not recognize the rays of such a radiant virtue, just as indeed many, even knowledgeable persons, along with Aristotle himself [lo stesso Filosofo], used to believe that the brain was formed by nature only in order to cool down the heart." ${ }^{49}$ As a matter of fact, in his On the Parts of the Animals, Aristotle upholds this notion: "This at any rate is clear: animals must of necessity have in them a certain amount of heat. Now, everything needs something to counterbalance it, so that it may achieve moderation and the mean ... for this cause nature has contrived the brain to counterbalance the region of the heart and the heart in it." ${ }^{50}$ In opposition to Aristotle's theory, Galen had already established that the brain did not perform any cooling, "for the brain is always found to be warmer to the touch than the air around us." 51 He further illustrates the basic structure and functions of the brain:

In substance the brain is very like the nerves, of which it was meant to be the source, except that it is softer, and this was proper for a part that was to receive all sensations, form all images, and apprehend all ideas. For a substance easily altered is most suitable for such actions and affections, and a soft substance is always more easily altered than one that is harder. This is the reason why the brain is softer than the nerves, but since there must be two kinds of nerves ... the brain itself was also given a twofold nature, that is, the anterior part [the cerebrum] is softer than the remaining hard part [the cerebellum]. ... Now the anterior part had to be softer because it was intended to be the source of the soft nerves leading to the sense instruments, and the posterior part had to be harder, being the source of the hard nerves distributed to the whole body. ${ }^{52}$

In Galen's interpretation of the brain's functions, the relative softness or hardness of the cerebrum and cerebellum depends on their receptivity. Because the brain is the hub of the nerves, its softer part is necessarily the one connected to those nerves that are more susceptible to impression, and hence "softer" given their higher degree of receptivity. These Galen calls "the sense instruments," declaring that "it is absolutely necessary for each of [them] to be altered if sensation is to occur. They are not, however, all altered by every

49. Scannelli, Microcosmo, 15.

50. Aristotle, Parts of Animals, Movement of Animals, Progression of Animals, ed. and trans. A. L. Peck and E. S. Forster (Cambridge, MA, 1945), 151.

51. Galen, On the Usefulness, 1:390.

52. Galen, On the Usefulness, 1:398. perceptible thing; rather, the bright, luminous sense instrument is altered by colors, the airlike instrument by sounds, the vaporous instrument by odors, and in a word, like is perceptible by like." In describing the functioning of the visual nerves, Galen insists that "none of the sense instruments except the instrument of vision will be altered by colors; for vision alone has a sense instrument that is radiant, pure, and glistening, namely the crystalline humor." Along the same lines, Galen notes that "it would be of no use for this alteration to take place unless it was recognized by the ruling principle which forms images, remembers, and reasons." Accordingly, the brain, he continues, "extends a part of itself to the crystalline humor in order to know how it is being affected." ${ }^{13}$ Galen defines the network of nerves between the brain and the eye "as an offshoot, which is soft like the brain." In order to prevent injury, this nerve becomes denser and more compact, but only temporarily, since it again thins out and regains its original character in nearing the cerebrum, "so that it appears to be the real brain in color, consistency, and all the other qualities." 54

That seeing and perceiving the object of vision occurs through a network of nerves that are most similar to the brain in their material configuration unquestionably meant for Scannelli that eye and brain, sight and soul, were intrinsically interrelated. In a sense, seeing is the soul's noblest operation; through seeing, the soul showcases its exceptional "softness," that is, its capability to receive, become impressed by, and process sensation. It is unclear whether Scannelli, in labeling Correggio the brain of painting, associated the painter's quintessential softness (morbidezza) to the softness characteristic of the brain and the optical nerves in Galenic medicine. Because physiological softness determines both the acuity and intensity of visual and mental perception, this possibility cannot be ruled out. Leaving this matter aside, in designating Correggio as the brain of painting, Scannelli intended to highlight the sensuous accuracy with which the master rendered nature and his ability to sublimate visual perception into spiritual vision. In other words, Correggio is the eye and soul of painting and, on this score, Correggio's painting is the most divine product of human sight and mind. In all fairness, it should be stressed that Scannelli mostly fails in his attempt to compellingly convey this message. Here is how Scannelli elucidates his identification of Correggio with the brain:

53. Galen, On the Usefulness, 1:402.

54. Galen, On the Usefulness, 1:402-3. 
Similarly, physicians have demonstrated that the brain is the noblest and most marvelous organ of the human microcosm, because it contains within itself the ventricles and astonishing cavities in which operates the prodigious activity of that plexus that, with regard to the effects commonly considered by the learned to partake in divinity, is usually defined as admirable [mirabile] and stupendous; in it the spirits of intellection are produced, not to mention the fact that there the vital spirits are further perfected so that later, through artifice and as a result of their rarefied conformation, they become fit to serve as the immediate means of reason. ${ }^{55}$

This is one of the most puzzling medical observations in Scannelli's Microcosmo. First Jacopo Berengario da Carpi (ca. 1460-ca. 1530), then more conclusively Andreas Vesalius (1514-64) had proved that the rete mirabile construed by Galen as the filtering mechanism of the soul was nowhere to be found in human beings (fig. 1). ${ }^{56}$ In this case, Scannelli either lagged behind in his knowledge of anatomical studies or deliberately ignored their findings. At any rate, he must have thought that Galen's views on the rete mirabile perfectly corresponded to his art-theoretical goal. In On the Doctrines of Hippocrates and Plato, Galen posits that the highest form of pneuma (a natural element necessary to human life), which proves to be "the first instrument of the soul," originates in the brain through a process of sublimation: ${ }^{57}$

And you would expect ... that this pneuma is produced when the vessels, especially the arteries, breathe it out into the ventricles of the brain, after you have seen the retiform web which is formed from the arteries that go to the head, as soon as they have entered the cranium and are inside it at the so-called base of the brain. . . . Now the pneuma in the arteries is and is called vital, and that in the brain is called psychic, not in the sense that it is the substance, but

55. Scannelli, Microcosmo, 18.

56. For Berengario da Carpi's discussion of Galen and his location of the rete mirabile, see Carpi commentaria cum amplissimis additionibus super anatomia Mundini (Bologna, 1521), ccclix ( $r-v)$. For Vesalius's refutation of the existence of Galen's rete mirabile, see A. Vesalius, De humani corporis fabrica libri septem (Basel, 1543), 642-43. See also G. A. Russell, "Vesalius and the Emergence of Veridical Representation in Renaissance Anatomy," in The Fine Arts, Neurology, and Neuroscience, ed. S. Finger, D. W. Zaidel, F. Boller, and J. Bogousslavsky (Amsterdam, 2013), 3-32.

57. On Galen and the pneuma, see L. G. Wilson, "Erasistratus, Galen, and the Pneuma," Bulletin of the History of Medicine 33 (1959): 293-314; J. Rocca, Galen on the Brain: Anatomical Knowledge and Physiological Speculation in the Second Century AD (Leiden, 2003); and P. J. van der Eijk, Medicine and Philosophy in Classical Antiquity: Doctors and Philosophers on Nature, Soul, Health, and Disease (Cambridge, 2005), 119-35.

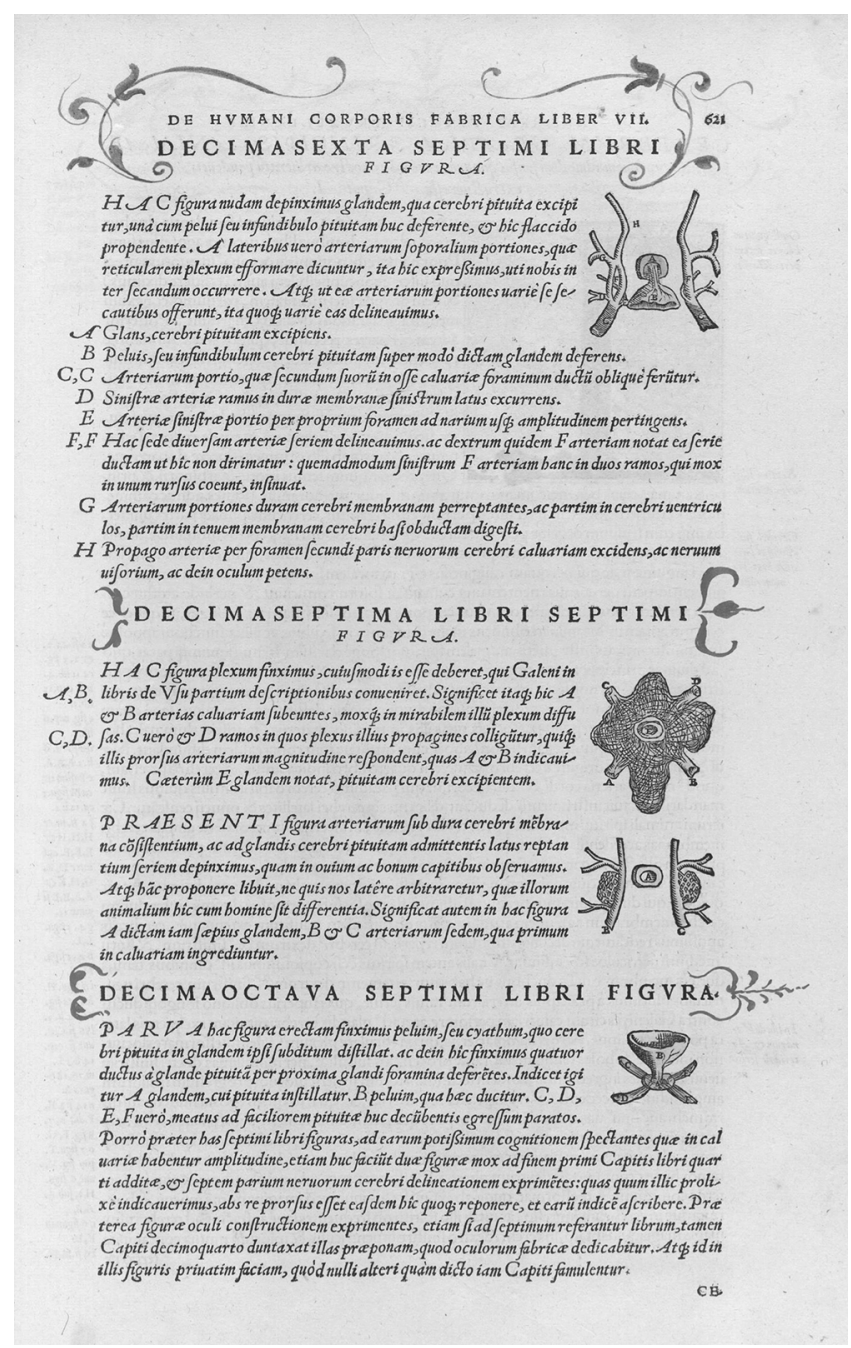

Figure 1. Andreas Vesalius, fictive reconstruction of Galen's rete mirabile, from De humani corporis fabrica (Basel, 1543), 621. Photo: Universitätsbibliothek Basel, AN I 15, https://doi .org/10.3931/e-rara-20094, Public Domain Mark. Color version available as an online enhancement.

rather the first instrument of the soul that resides in the brain, whatever its substance may be. Just as vital pneuma is generated in the arteries and the heart ... so the psychic pneuma is generated by a further refinement of the vital one. ... It is reasonable that also when making psychic from vital pneuma in the brain [nature] constructed close to the brain a complex labyrinth, so to speak, the retiform web. ${ }^{58}$

In expounding upon the function of the rete mirabile, Galen extols it as a portentous artifice of nature: "It is not a simple network, but looks as if you have

58. Galen, On the Doctrines of Hippocrates and Plato, ed. and trans. P. De Lacy (Berlin, 1978-84), 5:606-7. 


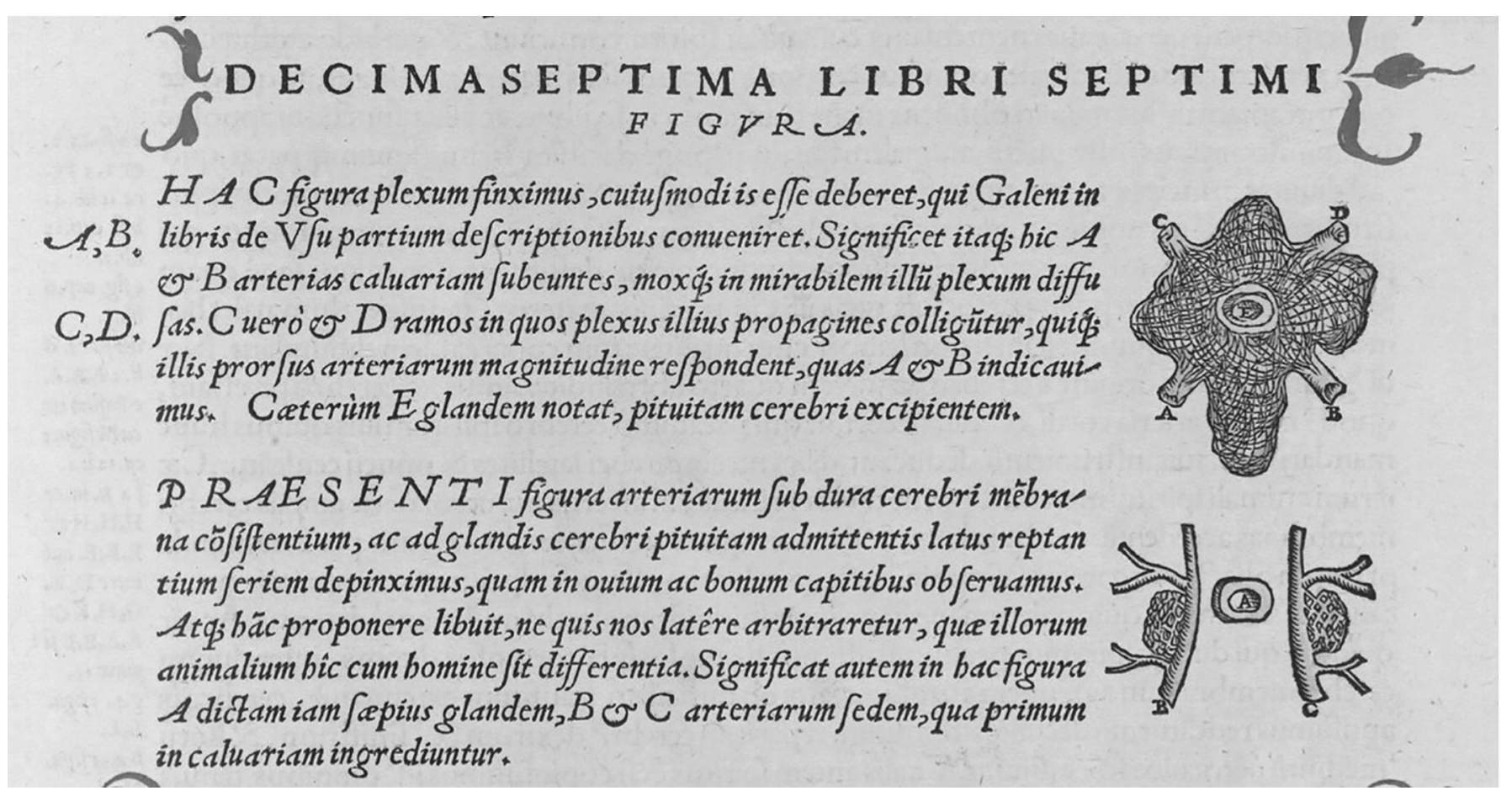

Figure 1. (cont'd.)

taken several fisherman's nets and superimposed them. It is characteristic of this net of nature's, however, that the meshes of one layer are always attached to those of another, and it is impossible to remove any of them alone ... but of course, on account of the delicacy of the members composing it and the closeness of its contexture, you could not compare this network to any man-made nets, nor has it been formed from any chance material." 159

Galen's description of the rete mirabile is key to our understanding of Scannelli's reading of Correggio. As discussed above, Scannelli compares the activity of both Raphael and Titian to an organic mechanism of distillation. The liver (Raphael) transforms the food (the ancient canon) into blood (delicacy of draftsmanship). This, in turn, is sublimated into life (vera carne) and delivered throughout the body (of painting) thanks to the heart (Titian). At the end of the process, Correggio (the brain) distills the true life of blood into living spirit by dint of the rete mirabile: the divinely soft sift of Correggio's eye and mind. In Scannelli's own words, the living spirit of painting is nothing but "the very beautiful idea of worthiest painting, where it can be said that ... the most rarefied spirits are distilled as if by means

59. Galen, On the Usefulness, 1:431. of an alembic; these are the pure extracts and true quintessence of beautiful and good painting." ${ }^{\prime 60}$ For Scannelli the body of painting works like a miraculous alembic: a divine filtering process transforming nature into vision as perceived through the purest eyes and mind of the soul. "Akin to nectar or any other celestial drink," Correggio's art manages "through sight to inebriate the senses of the greatest masters and keep them in ecstatic marvel." In brief, Correggio, "as the head of the human microcosm," is recognized as "the true seat of the most excellent operations." ${ }^{\prime 61}$ To his paintings "Raphael contributed the natural nourishment of well-grounded knowledge, through which one comes up with inventions of stories outstandingly represented, rare and lively dispositions with unusual and stupendous attitudes; [to his paintings] Titian further contributed spirit with strength and vigorous naturalness paired with fierce and impetuous motion." ${ }^{62}$ Whether initially lacking or in excess, all the qualities of Raphael and Titian are "thoroughly domesticated and moderated by the well-proportioned nature" of Correggio-the-brain. ${ }^{63}$ Built like a Matryoshka doll, Scannelli's body of painting

60. Scannelli, Microcosmo, 16

61. Scannelli, Microcosmo, 15.

62. Scannelli, Microcosmo, 15.

63. Scannelli, Microcosmo, 15. 
encases Raphael and Titian within the outer shell of Correggio, and it is for this reason that history - as the advancement of art over time-might well stop with Correggio. Indeed, it is impossible to surpass the master from Parma, and thus his legacy must be handed over to future generations and perpetuated as a model of everlasting perfection. In this regard, it also stands to reason that excellent masters unfortunate enough to have been born after Correggio end up being likened to merely secondary bodily organs. With the partial exception of Veronese, who plays the seminal role of being painting's genitalia owing to his inexhaustible "fertility," even the greatest reformers of contemporary painting, the Carracci and their disciples, qualify only as the "well-balanced skin and universal membrane" wrapping "the well-formed microcosm of painting." ${ }^{14}$ If there is evolution in Scannelli's art theory, this seems to take on the form of degeneration or, physiologically speaking, anomalous outgrowth:

\section{Just as the skin further generates the cuticle, the most ignoble and least necessary part of the human body, so too in our great body of painting other good masters from this school, but of lesser importance, serve as the cuticle, all of them concurring toward the external achievement of such a compound, so that it remains to add, in relation to the integral and necessary parts, those alone that on this occasion manifest themselves accidentally, which correspond for instance to the callous and hard excrescences in the body's outermost parts and other accretions of the outer cuticle, such as cosmetics and similar superfluous dressings. ${ }^{65}$}

Once fully clothed in its own skin, painting almost inexorably declines by falling prey to the vanity of exterior adornment. More specifically, Scannelli views contemporary painting as subject to a long-term disease: the spreading of the falsely pleasant "white manner," which he indeed diagnoses as the typical symptom of painting's aging body. ${ }^{66}$ There is not space here to comment on Scannelli's ideas about the decay of painting. However, it is this perception of decay that dictates the urgency of Scannelli's endeavor. An antidote to age and debilitation, the healthy body of painting as delineated by Scannelli is meant to restore good painting and sound spectatorship. Painting's health can only act

64. Scannelli, Microcosmo, 110.

65. Scannelli, Microcosmo, 110.

66. In this regard, see P. Sohm, The Artist Grows Old: The Aging of Art and Artists in Italy, 1500-1800 (New Haven, CT, 2007), 161-66; and L. Pericolo, "Whiteout: Self-Awareness and Self-Identity in Guido Reni's Non-Finito," in Proceedings of the 34th International Congress of Art History (Beijing, 2019), 1:490-501. upon a healthy beholder, but (and this is a sort of vicious circle) only the beholder acquainted with a canonical notion of painting will be effectively captured by the lure of the most perfect pictures. As the product of human vision, painting is activated through the viewer's sight. Seeing the work is tantamount to seeing through the eyes and mind of its author. Wholly persuaded of this principle, Scannelli likewise believes that experiencing the painting equates with scientific experimentation: the perfection of a work by Correggio can be verified by the viewer's reaction to it. The experiment of seeing is first and foremost a recognition: the equivalent of the Aristotelian anagnorisis. In a crucial and slightly convoluted passage of the Microcosmo, Scannelli remarks that "from the subsequent recognition of the works as specific expressions of the subjects, one will surmise the quality and effectiveness of the causes, because in this way one conforms with the most certain truth of the fact, whereas further quibbling with inveterate obstinacy against what is verified by the senses [l'esperimentato del senso] is considered in the end, when it comes to the wise, the effect of stuttering and weak comprehension." ${ }^{67}$ In Scannelli's estimation, painters and paintings are the physical causes of the sensations experienced by the viewer in appraising the work's subject matter and the ways in which it is developed by the painter. If there is "quality and effectiveness," the beholder will immediately recognize the conformity between visual rendition and thematic content. This recognition is not only rational, but it involves the senses at their deepest and moreover inspires the soul to a higher level of vision. Furthermore, Scannelli states that this kind of recognition constitutes the strongest evidence in determining the work's authorship and its originality. For Scannelli, however, connoisseurship represents only the first step toward a thoroughly grounded knowledge and sophisticated appreciation of painting as a sensory, even voluptuous experience. In enumerating the effects caused by the best paintings, Scannelli follows a hierarchical and physiological order. At its highest stage, the work of art arouses the most intense and disrupting reactions in the viewer:

There [at the level of the spirits of the soul], the already conceived ideas of the greatest beauty present themselves to the imagination with the same appearance as the truth, albeit a fictive and fabricated one, and as such it is displayed on view to the human feelings. As a result, upon viewing beauty and almost divine grace depicted as if from

67. Scannelli, Microcosmo, 134. 
life, the senses all at once become overwhelmed by such excellent qualities, and thus cannot help but be moved to love and devotion, and by the same token, upon the appearance, as if alive, of profane beauty and sensuousness, they are induced into arousal and lust. ${ }^{68}$

It is irrelevant here that Scannelli condemns any sensual emotion awakened by painting, while he predictably praises those works that instill the purest feelings of devotion: these are destined to be venerated as "relics and signs more verisimilar and more greatly germane to divinity itself." ${ }^{69}$ What truly matters is the mechanism through which the viewer perceives and processes the picture. In conformity with seventeenth-century optics, Scannelli presupposes that the work interacts with the eye by emitting impressions of itself and of the figures and objects depicted in it. Man's most refined sensorial apparatus, the eyes, reacts to this network of impressions (species) with greater or lesser intensity, commensurately with the "density of truth" encoded within the image. When the vision supplied by the work is highly distilled, appropriately animated, and spiritualized (as if by painting's liver, heart, and brain), it undergoes a similar process of self-sublimation through the viewer's senses and mind. The perfection of Correggio's painting resides in equal measure in its unsurpassable naturalness (the eyes are fooled even as the brain presents the image to the senses as a mirror of an optically perceived nature) and in its eminent degree of beautification (objects and figures, events and actions appear in their purest form, distilled through the alembic of harmony and proportion, imagined by force of "inner cognition"). In this light, the divinity of Correggio's painting is accounted for on both aesthetic and theological grounds: "The bodies' harmony that is called beauty is nothing but a path through which one walks toward the cognition of God." 70 Needless to say, marvel and intoxication naturally arise when eye and mindthat is, the soul-see the true vision of transfigured nature.

In view of art's divine function, Scannelli's concept of painting as a body may be taken more literally. By representing the divine body, painting accomplishes its noblest task: the embodiment of divinity. At its most cogent, the body of painting is a duplicate of the human body in its most perfect form. In celebrating Titian's early Tribute Money (fig. 2), Scannelli asserts that the figure of Christ therein, "of all the figures that reveal the humanized divinity of the Blessed Redeemer with

68. Scannelli, Microcosmo, 131.

69. Scannelli, Microcosmo, 132.

70. Scannelli, Microcosmo, 131.

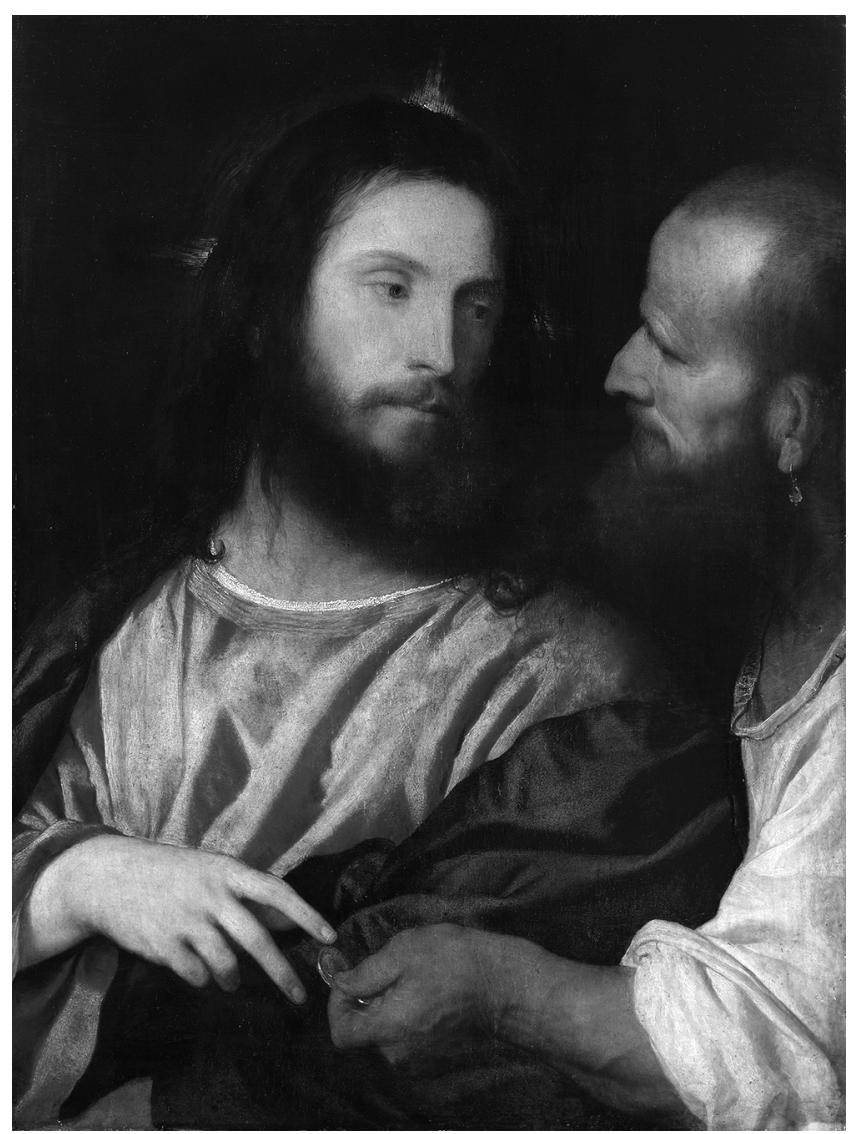

Figure 2. Titian (Tiziano Vecelli), The Tribute Money, ca. 1516. Oil on panel, $75 \times 56 \mathrm{~cm}$. Gemäldegalerie, Dresden, inv. 169. Photo: bpk Bildagentur / Gemäldegalerie Alter Meister, Staatliche Kunstsammlungen, Dresden / Elke Estel / Hans-Peter Klut / Art Resource, NY. Color version available as an online enhancement.

the greatest verisimilitude, is if not the rarest, at least the equal of any other deemed excellent, as it more strongly conforms with Lentulus's epistle." ${ }^{\prime 71}$ Scannelli refers here to the description of Jesus's physical appearance contained in an apocryphal fifteenth-century text: a letter purportedly sent by Publius Lentulus, the procurator of Judaea during the reign of Emperor Tiberius, to the Roman Senate. ${ }^{72}$ Without questioning its authenticity, Scannelli regards the epistle as the most accurate

71. Scannelli, Microcosmo, 230-31. On Titian's Tribute Money, now in the Gemäldegalerie, Dresden, see H. E. Wethey, The Paintings of Titian: Complete Edition, vol. 1, The Religious Paintings (London, 1969), 163-64, no. 147.

72. See C. E. Lutz, "The Letter of Lentulus Describing Christ," Yale University Library Gazette 50 (1975): 91-97. 
historical testimony of Christ's likeness. The supposed adherence of Titian's Christ to Lentulus's portrayal enhances the value, pertinence, and perfection of the work in Scannelli's eyes. "Along with the greater truth of history," Scannelli argues, the painting offers to Christians "what [their mind] at present could not possibly conceive unless imperfectly." Through Titian's image, Christ's true likeness indeed "manifests itself with extreme punctuality." ${ }^{\prime 73}$ That Scannelli attached great importance to painting's ability not only to evoke, but especially to recreate the divine body is confirmed by his discussion of Michelangelo's Cristo della Minerva, a sculpture of the resurrected Christ in Santa Maria sopra Minerva, Rome (fig. 3).$^{74}$ In his Trattato dell'arte de la pittura, Giovan Paolo Lomazzo had declared, to Scannelli's scandal, that Michelangelo's Christ, "which stands naked with the most beautiful attitude while holding the cross," had been executed on the example of Lentulus's description. ${ }^{75}$ Outraged, Scannelli challenges the reader to test Lentulus's letter against Michelangelo's work. Foreseeing the results of the comparison, Scannelli predicts that the Cristo della Minerva will be deemed defective. Knowledgeable artists in effect know that, "in representing the humanity of Christ," "grace and a singular commixture of rare delicacy" are required. ${ }^{76}$ "The adequate depiction of the figure of the humanized God," Scannelli remarks, "is nothing but the epitome of the greatest difficulties and the worthiest and most qualified beauties that painting can ever display before the eyes of good artists." 77

When assessed from the vantage point of its theological foundations and religious purposes, Scannelli's Microcosmo may prove as a rather conservative enterprise: it aligns itself not only with the theoretical tenets of the Counter-Reformation, but (well beyond these) with an ideal of painting that could qualify as both neoscholastic and Neoplatonic. However, when scrutinized in light of its methodology, Scannelli's work for all its limitations emerges as the product of conceptual innovation and earnest reflection

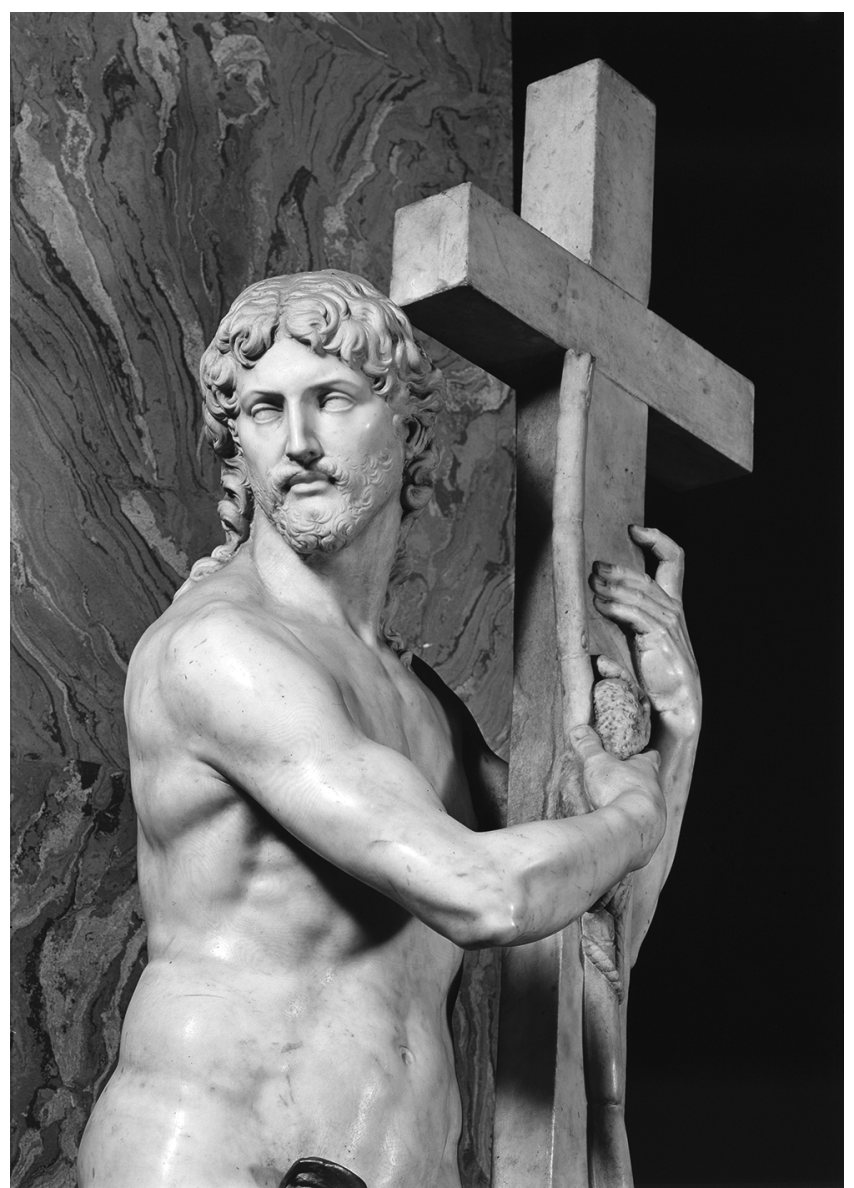

Figure 3. Michelangelo Buonarroti, Christ Risen, 1519-20 (detail of bust). Marble. Santa Maria sopra Minerva, Rome. Photo: Scala / Art Resource, NY. Color version available as an online enhancement.

on the nature and function of the image. Far from being the automaton theorized by Descartes and dreamt of by Hobbes, Scannelli's body of painting is a selfanimated construct of aesthetic perfection and religious contemplation: the bizarre creature of a slightly retrograde physician utterly fond of pictures.

73. Scannelli, Microcosmo, 231.

74. On Michelangelo's Risen Christ, see C. de Tolnay, Michelangelo, vol. 3, The Medici Chapel (Princeton, NJ, 1948), 89-95.

75. G. P. Lomazzo, Trattato dell'arte della pittura, scoltura et architettura (Milan, 1584), 531.

76. Scannelli, Microcosmo, 282.

77. Scannelli, Microcosmo, 282. 